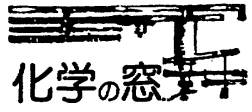

\section{アミノ酸を不斉源とする 光学活性リン化合物の合成}

下式のタイプのリン化合物は, 殺虫撤, 除草剤として

$$
>\mathrm{P}=\mathrm{X}(\mathrm{X}=\mathrm{O}, \mathrm{S})
$$

広く利用されている．その作用機作，代謝過程などの解 明には光学活性体がしばしば利用され(1)，Fukuto(2)，江 藤(3)，大川年 らの研究はよく知られている。しかしなが ら，光学活性リン化合物の合成法にはこれまで，沉用性 のあるすぐれたものが知られていなかった。すなわち， (1)どのような不斉源を用いるのか，(2)どのような方法で 光学分割（ジアステレオマー分離）するか，の 2 点が経 験や試行錯誤に依存していたため，かなり難しい研究対 象といわざるをえない状態であった。

筆者らはここ数年来, 光学活性リン化合物を確実に合 成する手法を確立することを目的として研究を行なって おり，ほぼその目的を達成できたので，以下その結果と 応用について簡単に 紹介することにしたい(Inch ら は $l$-エフェドリンを不斉源とする合成法を筆者らとほ ぼ同時期に発表して扰り，この方法も非常にすぐれた方 法であるが，紙面の都合上ここでは割愛する. Inch ら の方法により合成した ${ }^{18} \mathrm{O},{ }^{17} \mathrm{O}$-含有光学活性りン酸エ ステル類を用いる酵素反応機構の研究などについては小 文(6)を参考にしていただきたい).

\section{$\square$}

筆者らは 1976 年頃まで，ホスホラスアミド類(下式の<smiles>CN(C)P(C)(C)=O</smiles>

構造を有する化合物の総称）の化学的性質を動力学およ び立体化学的側面から研究し, 稀酸中での酸触媒 P-N 結合切断反応は典型的な $S_{\mathrm{N}} 2$ 反応であり，100\% 立体 反転で進行することを明らかにした(7).ささて，このょう な事実を基礎に考えてみると，光学活性アミンとホスホ
ラスクロリドを反応させてホスホラスアミドを合成し， そのジアステレオマーが分離できれば，式1のように各 種の光学活性ホスホラスエステルが光学純度 100\% で得 られるはずである。

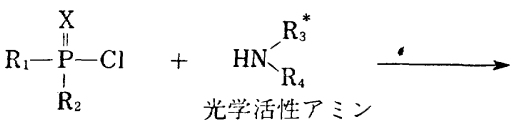

$(\mathrm{X}=\mathrm{O}, \mathrm{S})$
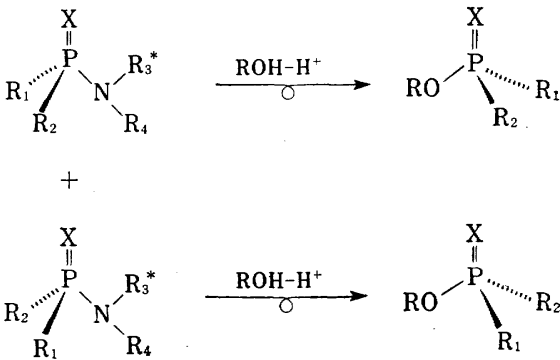<smiles>[R][PH]([R])([R])[R]</smiles>

$\mathrm{R}_{3} *$ : 不斉炭素を有する

アルキル基

（式 1)

そこで, (1)不斉源としては大量入手が可能な Lーアミノ 酸エステルを用い，(2)ジフスレテオマーの分離には実験 技術の影響が出やすい再結晶などの代わりにクロマトグ ラフィを用いることを基本方針として実験を開始した。

まずはじめに，研究開始当時，化学的合成法のまった く報告されていなかった光学活性フェニルジアルキルリ ン酸エステルを合成することにした。フェニルリン酸ジ クロリドに対してトリェチルアミン存在下にアミノ酸エ ステル（H-AA-OEt）を反応させ，さらにエタノールを 反応させることにより，下に示寸ホスホールアミデート がジアステレオマー混合物として得られる（式 2 ).

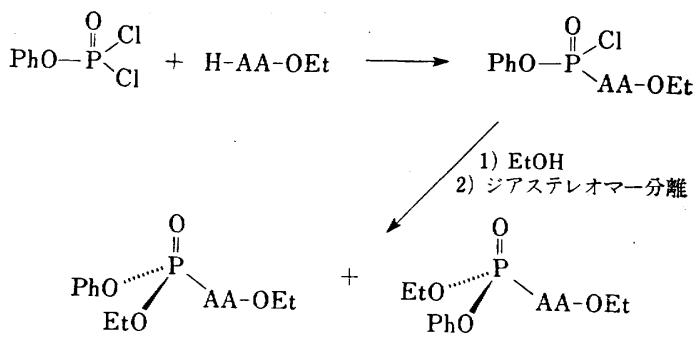
（式2）

得られたジアステレオマー混合物の分離を種々検討し たところ、アミノ酸エステルとして L-プロリンエチル エステル（H-Pro-OEt）を用いた場合に最も分離が容易 であることが明らかになった。得られたホスホールアミ デート（1，2）をそれぞれ 1 м 硫酸一メタノールでメタノ リシスを行なったところ, 光学純度ほぼ 100\%のエチル 
メチルフェニルリン酸エステル $(3)$ を収率よく得ること ができた(8) (式 3 ).

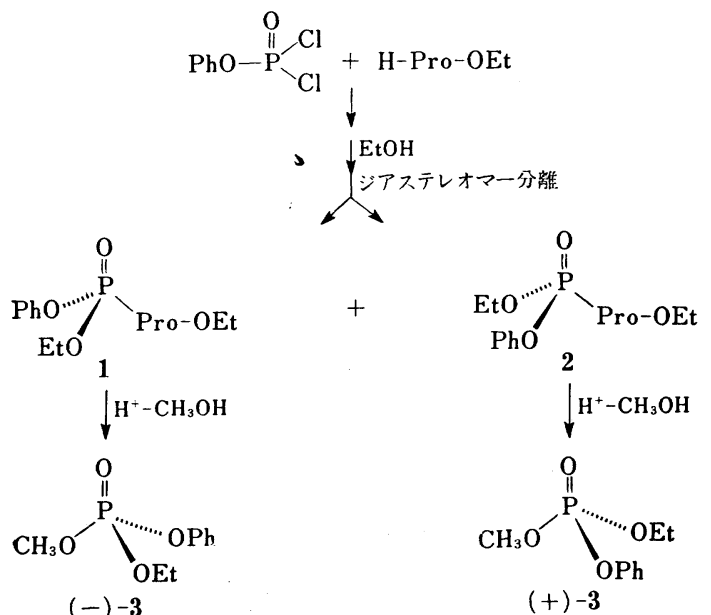

(式3)

光学純度の決定は NMR シフト試薬 $\operatorname{Eu}(h f c)_{3}$ を用 いて行なったが，この方法の確認限界は土 $2 \%$ 以下であ ク，2\%以上のエナンチオマーが存在しないことは確実 である.ちなみに，その後合成したほとんどの光学活性 ホスホラスエステル類の光学純度は NMR シフト試薬を 用いて決定しているが, $\mathrm{Eu}(h f c)_{3}$ または $\mathrm{Eu}(t f m c)_{3}$ が 最も効果的であった. 最近発売されている光学活性体分 離用カラム（chiral PAK(十)-T など）を用いる HPLC る有用な方法と思われる.ここで得られたエチルメチル フェニルリン酸エステル(一)-3 の絶対構造は, 絶対構 造既知の ethyl L-phenylalaninate の methyl phenyl phosphoramidate $(R)_{\mathrm{P}}-\mathbf{4}^{(9)}$ を酸触媒エタノリシスした ところ（一)-3 が得られたことから， $S$ 配置であること がわかった（式 4 ）.<smiles>CCOC(=O)C(Cc1ccccc1)NP(=O)(O)[Po](=O)(O)OCC</smiles>
$(R)_{\mathrm{P}}-\mathbf{4}$

（式4）

また，上記ホスホールアミデート 1, 2 を各種のアル コールと酸触媒存在下で反応させて, 絶対構造のわかっ た光学活性アルキルエチルフェニルリン酸エステルを高 光学純度で得ることもできた. ちなみに，同様の方法で (十)扰よび(一)ーエチルメチル $p$-ニトロフェニルリン酸 エステルを合成し, 殺虫作用, コリンエステラーゼ阻害 活性を調べたところ，イエバェ，アカイエカ，ツマグロ
ヨコバイのいずれに対しても(一)体のほうが活性が強い ことがわかっている.

以上, 光学活性リン酸トリエステル類の 合成に L-プ ロリンエチルエステルが有用であることが明らかとなっ たので, 同様の方法を光学活性ホスフィネート, ホスホ ネート類に適用したところ，下のような場合にいずれも ジアステレオマーの分離が容易であり，高い光学純度で 目的のホスホラスエステルが得られた(10).<smiles></smiles><smiles>CCO[Po]P(=O)(O)[Pb](=O)c1ccccc1</smiles>
$6^{(106)}$<smiles>CCO[Po]P(=S)(Cl)c1ccccc1</smiles>
$8^{(10 \mathrm{c})}$<smiles>CCOP(=O)(OCC)P(=O)(Cc1ccccc1)c1ccccc1</smiles><smiles>CC=CP(=O)(OCC)OCC</smiles><smiles>CC=C([Se][Te])P(=O)(OCC)OCC</smiles>

現在, 筆者らの研究室では中圧カラムクロマトグラフ ィを用いて，常時 $10 \sim 50 \mathrm{~g}$ 量のジアステレオマー分離 を行なっており(シリカゲル 150〜250 g, 1 回注入試料 量 $1.5 \sim 2.5 \mathrm{~g}$ ), 中圧カラムクロマト用カラムの容量を 大きくすれば $100 \mathrm{~g}$ 以上の分離も支障なく行なえるはず である.この場合, シリカゲルは反復使用が可能であ り,クロマトグラフィによるジアステレオマー分離の難 点である吸着剤の高価さ，大量精製・分取の問題点も， ある程度克服できたものと考えている.

$\square$

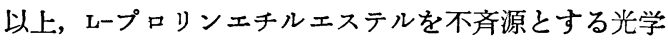
活性リン化合物の合成法について述べてきた. この方法 は非常に汎用性に富んでおり, 各種の生理活性リン化合 物の光学活性体の合成に際し相当確実に適用できるもの と考えている. この方法を用いて合成した光学活性リン 化合物の生化学, 農学, 薬学方面への応用は種々考学ら れるが，筆者らはこれら光学活性 リン化合物を有機合 
<smiles>CCOP(=O)(P)P(=O)(OCC)OCC</smiles>

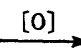

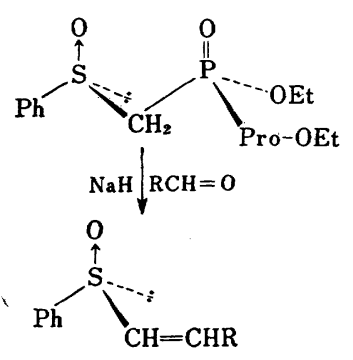

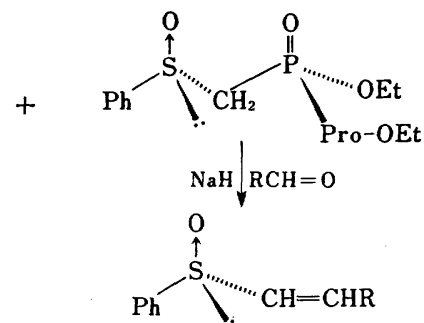

(式5)

成，特に高ジアステレオ選択的合成反応に利用すること を意図した研究も行なっている．現在までに得られたそ の知見の一部を次に紹介しょう.

1）光学活性 $\alpha, \beta$-不飽和スルホキシド類の合成

光学活性 $\alpha, \beta$-不飽和スルホキシド類は不斉反応の基 質として有用であることが土橋, Posner, 小泉(11)らに よって示されている. しかし，その合成法は光学活性ス ルフィネートを出発原料とするるのだけであり，限られ た範囲にしか適用できない次点がある．筆者らは，先に 合成したホスホンアミデート（9）を酸化したところ，対 応するスルホキシドがジアステレオマー混合物として得 られこれらも分離容易であることを見いだした，分離 後, Emmons-Horner 反応に付したところ，上式のよう に光学活性 $\alpha, \beta$-不飽和 スルホキシド類が 合成できた (式 5 ).

現在ジアステレオ選択的な酸化反応を検討中である が，これが完成すれば光学活性 $\alpha, \beta$-不飽和スルホキシ ド類の有用な合成法となるであろう。

2） $\alpha, \beta$-不飽和ホスホニル化合物を用いる不斉付加, 不斉 Michael 反応

先に合成した化合物 $\mathbf{1 0}$ に対し $\mathrm{PhSeCl}$ を付加させた ところ，90\%以上のジアステレオ選択性で付加反応が進 行した.また，ホスホンアミデート(11)に対する Mic-<smiles>CC=CP(=O)(OCC)POCC</smiles>

10 $\mathrm{PhSeCl}$<smiles>CCO[P+](=O)C([SbH])C(Cl)Cl</smiles><smiles>CCOP(=O)(OCC)C([Se])C(C)C</smiles>

11

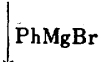<smiles>CCOC(=O)C(C(=O)OCC)C(C)[PbH]</smiles>

hael 反応もジアステレオ 選択的であることが最近明ら かになった（式6）.

以上， Lープロリンエチルエステルを不斉源として用い る光学活性リン化合物の合成拉よびその応用について述 べた. 光学活性りン化合物の生化学的, 薬理学的応用を 考えておられる読者諸氏にとって，その合成がさ汪ど困 難なものではないと考えていただくきっかけに本稿がな れば,これ以上の喜びはない。

1）宮崎昭雄：化学之生物，21，813 (1983).

2) G.H.Y.Lin, D.A.Wustner, T.R. Fukuto \& R.M. Wing : J. Agr. Food Chem., 22, 1134 (1983).

3) A. Hirashima \& M. Eto : Agric. Biol. Chem., 47, 2831 (1983).

4) H. Ohkawa, N. Mikami \& J. Miyamoto: Agr. Food. Chem., 41, 369 (1977).

5) C. R. Hall \& T. D. Inch : J.Chem. Soc. Perkin Trans. I, 1979, 1104 .

6）小泉 徽: ファルマシア, 18, 1079 (1982).

7）小泉 徹: 有機合成化学協会誌, 34, 137 (1976).

8) T. Koizumi, Y. Kobayashi, H. Amitani \& E. Yoshii : J.Org. Chem., 42, 3459 (1977).

9) T. Koizumi, Y. Kobayashi, E. Yoshii, M. Takamoto, K. Kamiya \& H. Asakawa : Tetrahedron Lett., 21, 3995 (1980).

10) a) T. Koizumi, H. Amitani \& E. Yoshii : Synthesis, 1979, 110

b) T. Koizumi, H. Amitani \& E. Yoshii : Tetrahedron Lett., 1978, 3741.

c) T. Koizumi, H. Takagi \& E. Yoshii : Chem. Lett., 1980, 1403.

d) T. Koizumi, M. Iwata, N. Tanaka, K. Hirutani \& E. Yoshii :Chem. Pharm. Bull., 31, 4195 (1983).

e) T. Koizumi, M. Iwata, N. Tanaka \& E. Yoshii : Chem. Pharm. Bull., 31, 4198 (1983).

f）小泉 徹, 田中信行：未発表データ.

11) T. Koizumi, H. Hirai \& E. Yoshii : J.Org. Chem., 47, 4004 (1982) およびその引用文献.

(小 泉 微, 富山医科薬科大学) 